\title{
STRATEGI PEMBELAJARAN GURU PAI DALAM MENGATASI KESULITAN KEGIATAN BELAJAR MENGAJAR PADA ERA PANDEMI COVID-19
}

\author{
Sari Sartika Lubis, Siti Istiqomah \\ Institut Ilmu Al-Qur'an Jakarta \\ sarisartika98.ss@gmail.com, siti.istiqomah@iiq.ac.id
}

\begin{abstract}
This research aims to determine the application of learning strategies carried out by schools, especially PAI teachers in overcoming the difficulties of teaching and learning activities in grade 4 SD Dua Mei Ciputat. The method used in this research is qualitative with qualitative descriptive research. Data collection techniques using interviews, observation and documentation. Primary data sources come from school principals, PAI teachers, and 4th grade students, while secondary data sources come from school data, books, journals, articles and theses. The data analysis technique uses a data reduction model, data presentation, and data verification or conclusions. The results of this study indicate that the implementation of contextual learning strategies has been going well. This is seen from several aspects, namely PAI teachers have planned learning strategies in the era of the covid-19 pandemic, minimized difficulties in online teaching and learning activities and collaborated in online teaching and learning activities with parents. The supporting factors in carrying out online learning include learning strategy innovations, assistance with school wifi facilities for teachers and good coordination between parents and teachers. While the inhibiting factors are the internet network which is less stable, there are some parents who do not understand the use of the internet and the competence of students decreases.
\end{abstract}

Keywords: Learning Strategy, Islamic Studies, Pandemic Covid-1.

\begin{abstract}
Abstrak
Penelitian ini bertujuan untuk mengetahui penerapan startegi pembelajaran yang dilakukan oleh sekolah khususnya guru PAI dalam mengatasi kesulitan kegiatan belajar mengajar di kelas 4 SD Dua Mei Ciputat. Metode yang digunakan dalam penelitian ini adalah kualitatif dengan jenis penelitian deskriptif kualitatif. Teknik pengumpulan data menggunakan metode wawancara, observasi dan dokumentasi. Sumber data primer berasal dari kepala sekolah, guru PAI, dan murid kelas 4, sedangkan sumber data sekunder berasal dari data-data sekolah, buku, jurnal, artikel dan skripsi. Teknik analisis data menggunakan model reduksi data, penyajian data, dan verifukasi data atau kesimpulan. Hasil penelitian ini menunjukkan bahwa penerapan strategi pembelajaran kontekstual sudah berjalan dengan baik. Hal ini dilihat dari beberapa aspek, yaitu guru PAI telah menyusun perencanaan strategi pembelajaran pada era pandemi covid-19, meminimalisir kesulitan dalam kegiatan belajar mengajar online dan bekerja sama dalam kegiatan belajar mengajar online bersama orang tua siswa. Adapaun faktor pendukung dalam melaksanakan pembelajaran online meliputi inovasi strategi pembelajaran, bantuan fasilitas wifi sekolah terhadap guru dan koordinasi yang baik antara orang tua dan guru. Sedangkan faktor penghambatnya jaringan internet yang kurang stabil, adanya beberapa orang tua yang belum mengerti dalam penggunaan internet dan kompetensi siswa menurun.
\end{abstract}

Kata Kunci: Strategi Pembelajaran, Pendidikan Agama Islam, Pandemi Covid-1. 


\section{PENDAHULUAN}

Kondisi pandemi Covid-19 yang sudah berlangsung selama satu tahun lebih, terhitung dari Maret 2020 hingga saat ini,telah mempengaruhi hampir semua aspek kehidupan manusia, seperti sosial, pendidikan, ekonomi, dan sebagainya. Untuk memutus mata rantai penularan Covid-19, banyak kebijakan yang dibuat oleh pemerintah Indonesia seperti anjuran berdiam diri di rumah, pembatasan sosial, pembatasan fisik, penggunaan alat pelindung diri (masker), menjaga kebersihan diri (cuci tangan), bekerja dan belajar di rumah, menunda semua kegiatan yang mengumpulkan orang banyak, dan Pembatasan Sosial Berskala Besar (PSBB).

Salah satu aspek yang terdampak besar saat ini adalah dunia pendidikan, sehingga pemerintah membuat kebijakan dengan merubah sistem kegiatan belajar mengajar dari pembelajaran tatap muka menjadi pembelajaran jarak jauh. Hal ini sesuai dengan peraturan Menteri Pendidikan dan Kebudayaan Republik Indonesia terkait Surat Edaran No 4 Tahun 2020 tentang Pelaksanaan Kebijakan Pendidikan Masa Darurat Dalam Penyebaran Corona Virus Disease (Covid-19). ${ }^{1}$

Saat ini, salah satu sistem yang dipakai dalam dunia pendidikan adalah Pembelajaran Jarak Jauh (PJJ) atau daring (dalam jaringan). PJJ merupakan sistem pembelajaran tanpa tatap muka secara langsung antara guru dan siswa yang dilakukan secara online dengan menggunakan jaringan internet. Pembelajaran daring merupakan salah satu bentuk dari penyampaian pembelajaran konvensional yang diterapkan dalam format digital melalui jaringan internet. Pada saat PJJ, guru harus selalu memastikan kegiatan belajar mengajar tetap berjalan dengan efektif, meskipun secara tidak langsung atau online. ${ }^{2}$

Peralihan pembelajaran tatap muka ke PJJ menimbulkan banyak kesulitan dan hambatan,diantaranya akses internet yang tidak lancar di berbagai daerah tertentu, kurangnya pengetahuan orang tua dan siswa dalam penggunaan teknologi, kurangnya pengawasan terhadap kedisiplinan siswa, dan sebagainya. Dari kesulitan-kesulitan tersebut, guru diharuskan untuk membuat strategi pembelajaran yang dapat meminimalisir terjadinya kesulitan dan hambatan kegiatan belajar mengajar di masa pandemi.

Strategi mulanya digunakan pada lingkungan militer, namun sekarang strategi bisa digunakan dalam berbagai bidang yang mempunyai esensi yang relatif sama termasuk dalam pembelajaran. Secara umum, strategi adalah garis-garis haluan untuk bertindak dalam usaha untuk mencapai tujuan yang telah ditentukan Strategi pembelajaran mencakup pendekatan, model, metode, dan teknik pembelajaran secara spesifik. ${ }^{3}$

Menurut J.R. David strategi pembelajaran adalah perencanaan yang berisi tentang rangkaian kegiatan yang didesain untuk mencapai tujuan tertentu. Sedangkan menurut Dick and Care, strategi pembelajaran merupakan satu set materi dan prosedur

\footnotetext{
${ }^{1}$ Ali Sadikin, Pembelajaran Daring di Tengah Wabah Covid-19, dalam Jurnal Pendidikan Biologi,Universitas Jambi, 2020, Vol.6, No.02, h.220

${ }^{2}$ Asrilia Kurniasari, dkk. Analisis Efektivitas Pelaksanaan Belajar Dari Rumah Selama Pendemi Covid-19, dalam Jurnal Kajian Pendidikan dan Hasil Penelitian, Vol.6 No.3 2020.hal.10

${ }^{3}$ Haudi, Strategi Pembelajaran, (Sumatra Barat: Insan Cedika Mandiri, 2021), h.1
} 
pembelajaran yang digunakan bersama-sama untuk menimbulkan hasil belajar siswa. ${ }^{4}$ Dari pengertian tersebut, dapat disimpulkan bahwa strategi pembelajaran adalah sebagai pusat informasi yang menyajikan langkah-langkah yang dipakai sebagai acuan dalam suatu proses pembelajaran.

Dalam penerapan strategi pembelajaran, orang yang memiliki peran paling penting adalah guru. Guru merupakan pusat pengendalian atau disebut juga sebagai pusat informasi dalam suatu kegiatan belajar mengajar. Oleh karena itu, sebelum menentukan strategi pembelajaran yang akan digunakan, ada beberapa pertimbangan yang harus diperhatikan, yaitu pertimbangan yang berhubungan dengan suatu tujuan yang ingin dicapai, pertimbangan yang berhubungan dengan bahan materi dalam pembelajaran, pertimbangan dari kondisi siswa, dan pertimbangan lainnya. ${ }^{5}$

Pada kondisi saat ini, strategi yang dipakai oleh guru sangat mempengaruhi keefektifan kondisi kelas.Hal ini dikarenakan banyak siswa yang mengalami kesulitan dan tidak terlalu fokus saat berlangsungnya pembelajaran jarak jauh. Kondisi ini membuat siswa menjadi jenuh dan bosan saat mengikuti kegiatan belajar mengajar. Akibatnya, banyak siswa yang mengalami penurunan di masa pembelajaran jarak jauh, baik itu dari segi pengetahuan maupun hasil belajar mereka dibandingkan dengan saat pembelajaran tatap muka.

Pendidikan anak Sekolah Dasar (SD) adalah salah satu sektor pendidikan yang terdampak di era pandemi saat ini. Hal ini dikarenakan rata-rata anak SD di Indonesia belum paham dalam menggunakan teknologi yang sangat penting dalam proses pembelajaran jarak jauh, termasuk di SD Dua Mei Ciputat yang telah menerapkan sistem PJJ.Banyak keluhan tentang kesulitan dalam memahami materi pelajaran yang dilaksanakan secara online di SD Dua Mei Ciputat.

Jadi, selain strategi pembelajaran dari guru, juga harus adanya kerjasama antara guru dan orang tua siswa agar dapat menunjang kegiatan belajar mengajar di era pandemi saat ini. Pada kondisi saat ini, siswa yang berada di jenjang dasar atau SD sangatlah membutuhkan perhatian khusus saat melakukan kegiatan belajar mengajar jarak jauh atau online.Oleh karena itu,sangat penting bagi guru untuk menerapkan strategi pembelajaran yang baru dan inovatif sesuai kebutuhan dalam kondisi pandemi ini.Hal ini \]]bertujuan agar dapat meningkatkan fokus belajar siswa dan meminimalisir kesulitan selama kegiatan belajar mengajar, sehingga siswa dapat memperoleh hasil belajar yang lebih baik, terutamadi SD Dua Mei Ciputat.

Berdasarkan masalah-masalah tersebut, penulis tertarik untuk melaksanakan penelitian yang berjudul 'Strategi Pembelajaran Guru PAI dalam Mengatasi Kesulitan Kegiatan Belajar Mengajar di Kelas 4SD Dua Mei Ciputat pada Era Pandemi Covid-19'

\footnotetext{
${ }^{4}$ Ngalimun, Strategi Pembelajaran, (Yogyakarta: Parama Ilmu, 2017), h.2-4

${ }^{5}$ Wina Sanjaya, Strategi Pembelajaran Berorietasi Standar Proses Pendidikan, (Jakarta: Kencana Prenadamedia Group,2006) h.129-130
} 


\section{METODE PENELITIAN}

Metode Penelitian yang digunakan dalam penelitian ini adalah metode kualitatif deskriptif. Penelitian kualitatif ini diterapkan untuk melihat dan memahami subjek dan objek penelitian yang berhubungan dengan manusia, dan lembaga yang berkaitan berdasarkan fakta dan apa adanya.

Teknik pengumpulan data menggunakan metode wawancara, observasi dan dokumentasi.m sumber data primer berasal dari kepala sekolah, guru PAI, dan murid kelas 4, sedangkan sumber data sekunder berasal dari data-data sekolah, buku, jurnal, artikel dan skripsi. Teknik analisis data menggunakan model reduksi data, penyajian data, dan verifukasi data atau kesimpulan.

\section{HASIL PENELITIAN}

Berdasarkan penelitian yang dilakukan peneliti selama 3 bulan, melalui proses pengumpulan data dengan melakukan observasi, wawancara dan dokumentasi tentang strategi pembelajaran guru PAI dalam mengatasi kesulitan kegiatan belajar mengajar di kelas 4SD Dua Mei Ciputat pada era Pandemi Covid-19. Ditemukan bahwa strategi yang digunakan sebagai berikut:

\section{Strategi Pembelajaran Dalam Mengatasi Kesulitan Era Covid-19}

Strategi pembelajaran merupakan pendekatan umum serta rangkaian beberapa tindakan yang akan diambil dan dipakai guru untuk memilih beberapa metode pembelajaran yang sesuai di dalam pembelajaran, strategi pembelajaran yang menuntut partisifasi aktif peserta didik. ${ }^{6}$

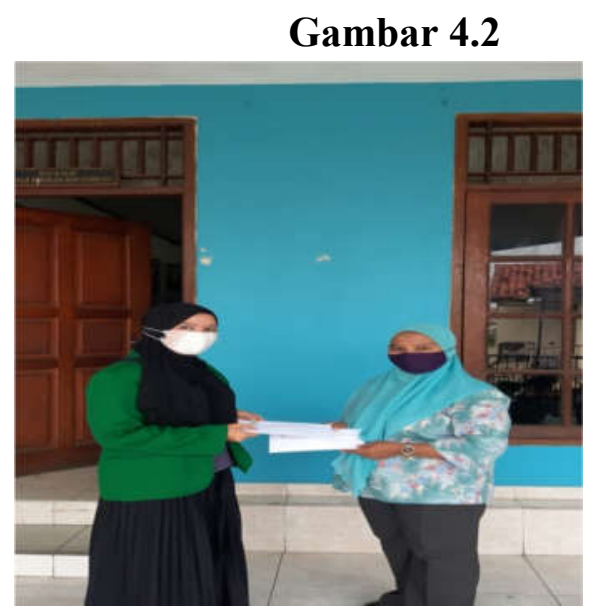

\section{Pemberian Surat Perizinan Penelitian}

Kepala sekolah merupakan jabatan tertinggi yang ada di lembaga sekolah. Kepala sekolah juga merupakan seorang penentu keberhasilan proses kegiatan belajar mengajar karena salah satu tugas utama seorang kepala sekolah adalah

\footnotetext{
${ }^{6}$ Haidir dan Salim, Strategi Pembelajaran: Suatu Pendekatan Bagaimana Meningkatkan Kegiatan Belajar Siswa Secara Transformatif, (Medan: Perdana Publishing, 2014), h.102
} 
mengatasi berbagai macam kesulitan dan masalah yang dihadapi oleh para guru dalam pelaksanaan pembelajaran. Pelaksanaan pembelajaran tidak akan efektif dan efisien jika kurangnya strategi pembelajaran yang dipakai oleh para guru apalagi di era pandemi covid-19 seperti saat ini.

Ibu Siti Badriyah, M.Pd.I, kepala sekolah SD Dua Mei Ciputat, menjelaskan bahwa "Strategi pembelajaran merupakan langkah-langkah yang dilakukan oleh para guru untuk mempermudah proses belajar mengajar". Sedangkan menurut Ibu Siti Qomariah M.Pd.I, guru PAI SD Dua Mei Ciputat, beliau mengutarakan bahwa "Strategi pembelajaran merupakan upaya yang dibuat oleh guru untuk mengatur kelancaran suatu pembelajaran dan melancarkan proses berlangsungnya kegiatan belajar mengajar agar tercapainya suatu kompetensi". ${ }^{8}$

Dari pengertian-pengertian tersebut, strategi pembelajaran dapat diartikan sebagai langkah-langkah yang dibuat oleh guru untuk memudahkan berlangsungnya proses pembelajaran dan tercapainya suatu kompetensi. Selain itu, strategi pembelajaran dapat juga didefinisikan dengan rangkaian kegiatan yang disusun secara sistematis yang di dalamnya terdapat metode-metode dan pemanfaatan berbagai sumber daya yang disusun untuk mencapai suatu tujuan yang diinginkan.

Gambar 4.3

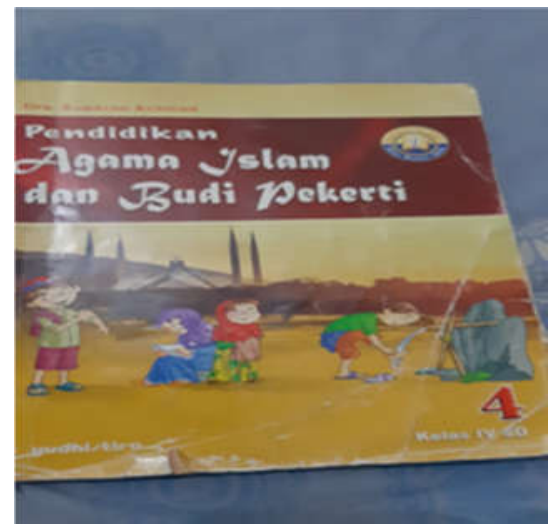

Buku PAI Kelas 4 SD Dua Mei Ciputat

SD Dua Mei Ciputat menggunakan beberapa jenis strategi pembelajaran seperti yang telah disebutkan kepala sekolah, Ibu Siti Badriyah, M.Pd.I. Dalam wawancara, beliau mengatakan "Guru-guru SD Dua Mei memakai strategi pembelajaran yang berbeda. Strategi pembelajaran yang dipakai tergantung pada materi yang sedang diajarkan". 9 Dari pemaparan dari Ibu Siti Badriyah, M.Pd.I, dapat diketahui bahwa strategi pembelajaran itu sangat penting dalam kegiatan Juni 2021

${ }^{7}$ Wawancara dengan Kepala Sekolah SD Dua Mei Ciputat, Siti Badriyah, M.Pd.I, Via WhatApp, 23

${ }^{8}$ Wawancara dengan Guru PAI SD Dua Mei Ciputat, Siti Qomariah, M.Pd.I, 16 Juni 2021

${ }^{9}$ Wawancara dengan Kepala Sekolah SD Dua Mei Ciputat, Siti Badriyah, M.Pd.I, Via WhatsApp, 23 Juni 2021 
belajar mengajar dan digunakan dengan menyesuaikan keadaan dan kondisi yang terjadi di kelas.

Saat ini, dunia sedang tidak sehat, termasuk Indonesia. Kita sedang mengalami kondisi darurat yang sangat berdampak pada semua aspek kehidupan, baik itu ekonomi, sosial, maupun pendidikan. Wabah ini disebut dengan Covid-19. Covid-19 merupakan wabah penyakit yang menyerang pernapasan manusia. Untuk mengurangi penyebaran Covid-19, pemerintah Indonesia telah melarang untuk mengadakan perkumpulan dengan menerapkan PSBB (Pembatasan Sosial Bersekala Besar). Tidak hanya itu, Kementrian Pendidikan telah menerapkan pembelajaran online atau PJJ selama Covid-19. ${ }^{10}$ Pembelajaran online adalah pembelajaran yang dilakukan dengan tanpa tatap muka, melainkan pembelajaran yang dilakukan secara online dengan menggunakan jaringan internet dan aplikasi penunjang pembelajaran. ${ }^{11}$

SD Dua Mei Ciputat juga telah menerapkan pembelajaran online. Hal ini sebagaimana apa yang dikatakan oleh kepala Sekolah, Ibu Siti Badriyah M.Pd.I, melalui wawancara "SD Dua Mei telah menerapkan pembelajaran jarak jauh, mulai dari ditetapkannya peraturan kementrian pendidikan selama pandemi ini""12

Selama berlangsungnya pembelajaran online banyak perubahan yang dirasakan oleh guru dan siswa, seperti adanya perubahan komunikasi dalam proses pembelajaran yang dilakukan tanpa tatap muka, maka selama pembelajaran online berlangsung menimbulkan beberapa kesulitan antara guru dan siswa, seperti kendala dalam terbatasnya komunikasi siswa dan guru secara langsung, kesulitan dalam melakukan kontrol aktivitas siswa selama pembelajaran, dan kesulitan dalam mengevaluasi dari hasil belajar siswa. Oleh karena itu, guru dituntut untuk berinovasi membuat strategi pembelajaran yang baik. ${ }^{13}$

Hal ini juga dirasakan oleh SD Dua Mei Ciputat, seperti yang disampaikan oleh Ibu Siti Komariah, M.Pd.I selaku guru di mata pelajaran PAI, beliau berpendapat "Selama melakukan proses kegiatan belajar mengajar online banyak kesulitan dan hambatan yang terjadi, seperti belum terlalu bisa beradaptasi dengan menggunakan strategi pembelajaran selama online, koneksi internet yang kurang stabil, kurangnya pengetahuan orang tua terhadap teknologi, dan kurangnya pengawasan kedisiplinan siswa selama pembelajaran online berlangsung". ${ }^{4}$ Adapun kesulitan yang dirasakan oleh salahsatu siswa kelas 4 yang bernama Mutia,

${ }^{10}$ Adi Muhammad Lutfi, dkk, Media Daring (Online) Solusi Pembelajaran Jarak Jauh, (Parepare: IAIN Parepare Nusantara Press, 2020), h.11

${ }^{11}$ Gilang, Pelaksanaan Pembelajaran Daring di Era Covid-19, (Banyumas: Lutfi Gilang, 2020), h. 17

${ }^{12}$ Wawancara dengan Kepala Sekolah SD Dua Mei Ciputat, Siti Badriyah, M.Pd.I, Via WhatsApp, 23 Juni 2021

\footnotetext{
${ }^{13}$ Lidia Susanti, Strategi Pembelajaran Online yang Inspiratif, (Jakarta: PT. Gramedia, 2021), h.3

${ }^{14}$ Wawancara dengan Guru PAI SD Dua Mei Ciputat, Siti Qomariah, M.Pd.I, 16 Juni 2021
} 
narasumber mengatakan bahwa "Saya merasa kesulitan dalam pembelajaran online karena terasa kaku dan membosankan, tidak seperti pembelajaran offline" ${ }^{15}$

Oleh karena itu, para guru SD Dua Mei menggunakan strategi pembelajaran yang dirasa lebih cocok dipakai selama pembelajaran online berlangsung. Hal ini sejalan dengan apa yang dikatakan oleh kepala sekolah, Ibu Siti Badriyah, M.Pd.I, "Selama pelaksanan pembelajaran online berlangsung, para guru di SD Dua Mei telah menggunakan strategi pembelajaran khusus online“. ${ }^{16}$ Dengan ini dijelaskan bahwa para guru SD Dua Mei Ciputat telah melakukan beberapa upaya untuk meminimalisir terjadinya kesulitan selama pelaksanaan pembelajaran online.

Termasuk yang dilakukan oleh guru PAI SD Dua Mei Ciputat, Ibu Siti Qomariah, M.Pd.I, beliau telah melakukan berbagai upaya selama pembelajaran online khususnya di kelas 4 SD. Dalam hal ini, Ibu Siti Qomariyah, M.Pd.I telah melakukan upaya penggunaan strategi pembelajaran yang berbeda-beda dalam pelaksanaan pembelajaran PAI di kelas 4. Berdasarkan hasil wawancara penulis dengan Ibu Siti Qimariyah, M,Pd.I, beliau menuturkan.

"Awal pembelajaran online saya menggunakan strategi pembelajaran langsung atau ekspositori di pelajaran PAI kelas 4, tetapi itu tidak berjalan lama dikarenakan dari hasil pengamatan saya selama pembelajaran online ini banyak siswa kelas 4 yang kurang mendapatkan hasil yang baik dari setiap pembelajaran berlangsung. Oleh karena itu, saya menggantinya dengan menggunakan strategi pembelajaran kontekstual. Dari strategi pembelajaran ini, pencapaian siswa kelas 4 lebih meningkat dibandingkan menggunakan strategi pembelajaran sebelumnya". ${ }^{4}$

Hal ini selaras dengan apa yang dirasakan oleh Rezki, salah satu murid kelas 4, narasumber mengatakan "Pada semester ganjil, Ibu guru PAI memakai metode ceramah yang membuat bosan dan tidak mudah dimengerti, tetapi pada semester genap ini, Ibu guru PAI menggunakan metode yang mengaitkan materi dengan kehidupan sehingga kelas terasa asik dan tidak membosankan".

Berdasarkan pemaparan guru PAI, Ibu Siti Qomariah, M.Pd.I, dan siswa kelas 4, dapat diketahui bahwa di SD Dua Mei Ciputat tersebut menggunakan dua strategi pembelajaran selama dilaksanakannya pembelajaran online, yaitu strategi pembelajaran langsung atau ekspositori dan strategi pembelajaran kontekstual. Namun, selama pembelajaran PAI berlangsung secara online, guru PAI lebih menyukai menggunakan strategi pembelajaran kontekstual karena dianggap lebih efektif.

Strategi pembelajaran langsung atau ekspositori adalah strategi pembelajaran yang menekankan kepada proses penyampaian suatu materi secara verbal atau lisan

\footnotetext{
${ }^{15}$ Wawancara dengan Guru Dua Mei Ciputat, Siti Qomariah, M.Pd.I, 16 Juni 2021

${ }^{16}$ Wawancara dengan Kepala Sekolah SD Dua Mei Ciputat, Siti Badriyah, M.Pd.I, Via WhatsApp, 23 Juni 2021
}

${ }^{17}$ Wawancara dengan Guru PAI SD Dua Mei Ciputat, Siti Qomariah, M.Pd.I, 16 Juni 2021 
kepada siswa agar siswa mampu untuk berfikir kritis dalam menguasai setiap materi yang sedang diajarkan. ${ }^{18}$ Kemudian, strategi pembelajaran tersebut diganti dengan strategi pembelajaran kontekstual. Strategi pembelajaran kontekstual adalah proses pembelajaran yang bersifat holistik dan bertujuan membantu siswasiswa untuk memahami makna dari materi pembelajaran dengan mengaitkannya terhadap konteks kehidupan mereka dalam kehidupan sekitar, baik sosial ataupun pribadi sehingga siswa dapat memiliki kemampuan yang dinamis dan fleksibel dari pemikiran mereka. ${ }^{19}$

Jadi, dapat disimpulkan strategi pembelajaran ekpositori atau langsung adalah strategi pembelajaran yang berpusat kepada guru, karena guru menjadi pemeran utama di dalam strategi pembelajaran ini. Oleh karena itu, dalam strategi pembelajaran ini, guru dituntut untuk dapat menguasai bahan ajar dengan baik dalam menyampaikan materi pelajaran. Adapun strategi pembelajaran kontekstual adalah strategi pembelajaran yang menghubungan materi pelajaran dengan keadaan atau situasi di lingkungan sekitar. Strategi pembelajaran kontekstual ini bertujuan agar setiap siswa dapat memahani makna pembelajaran dengan baik dan dapat diaplikasikan ke dalam kehidupan mereka.

Tiap strategi tentunya memiliki kelebihan dan kelemahan jika dibandingkan dengan strategi lainnya. Hal inilah yang menjadikan penggunan sebuah strategi menjadi kondisional. Adapun kelemahan strategi pembelajaran langsung dan ekspositori, adalah sebagai berikut:

a. Strategi pembelajaran ini mungkin tidak bisa digunakan untuk siswa yang memiliki kemampuan yang kurang dalam memahami.

b. Strategi ini tidak bisa untuk melayani perbedaan siswa dalam kemampuan dan gaya belajar.

c. Keberhasilan strategi ini sangat tergantung pada guru.

Sedangkan kelebihan strategi pembelajaran langsung atau ekspositori, adalah sebagai berikut:

a. Strategi ini bisa mengontrol urutan pada materi pembelajaran.

b. Strategi ini bisa dikatakan efektif apabila siswa memiliki kemampuan yang luas.

c. Memudahkan guru dalam memberikan materi dengan menggunakan metode ceramah. ${ }^{20}$

\footnotetext{
${ }^{18}$ Gestiana Ragin, dkk, Implementasi Strategi Pembelajaran Ekspositori untuk Meningkatkatkan Hasil Belajar Matematika di Sekolah Dasar: Jurnal Pendidikan Dakwah. Universutas Muhammadiyah Tangerang, 2020, Vol.02, No 1, h.55

${ }^{19}$ Nurdyansyah dan Eni Fariyatul Fahyuni, Inovasi Model Pembelajaran, (Sidoarjo: Nizamia Learning Center, 2016), h.37

${ }^{20}$ Suryadi, Strategi Pembelajaran Pendidikan Karakter, (Bandung: PT. Remaja Rosdakarya, 2013), h. $158-159$
} 
Sebagaimana strategi pembelajaran langsung atau ekspositori, strategi pembelajaran kontekstual juga memiliki kekurangan dan kelebihan. Adapun kelebihan dalam menggunakan strategi pembelajaran kontekstual, adalah sebagai berikut:

a. Memberikan kesempatan pada siswa unutk bisa maju terus sesuai pontensi yang dimiliki.

b. Memberikan kesadaran dan pemahaman kepada siswa tentang apa yang telah mereka pelajari.

c. Pembelajaran menjadi lebih menyenangkan dan tidak membosankan.

Sedangkan kelemahan dari strategi pembelajaran kontekstual, adalah sebagai berikut:

a. Tidak semua siswa bisa dengan mudah untuk menyesuaikan diri dan kemampuan yang dimiliki dalam strategi ini.

b. Dalam proses menggunakan strategi ini harus memiliki kemampuan tinggi dan harus mempunyai percaya diri agar tidak tertinggal materi.

c. Ketika siswa tidak bisa mengekspresikan diri dalam menghubungan pelajaran dan lingkungan sekitar membuat siswa merasakan kesulitan. ${ }^{21}$

Setiap strategi mempunyai kelebihan dan kelemahan masing-masing. Oleh karena itu, setiap strategi pembelajaran harus bisa menyesuaikan keadaan yang sedang terjadi selama proses pembelajaran berlangsung agar strategi pembelajaran berjalan dengan baik dan mencapai tujuan yang diinginkan.

Ibu Siti Qomariah, M.Pd.I mengatakan "Selama menggunakan strategi pembelajaran langsung atau ekspositori, banyak kendala dan kesulitan yang saya rasakan terutama pada pencapaian dan pemahaman siswa kelas 4, karena strategi ekspositori terlalu monotan dan membosankan. Strategi ini semakin kurang efektif karena sering kali saat saya sedang menjelaskan panjang lebar tiba-tiba koneksi internet mengalami gangguan sehingga apa yang disampaikan tidak terlalu jelas padahal sebelum pembelajaran online dilaksanakan saya menggunakan strategi pembelajaran ekspositori tetapi tidak banyak kendala dibandingkan pembelajaran online. "22

Hal ini sangat berkaitan dengan kondisi kesulitan yang dirasakan juga oleh setiap tenaga pendidik. Tenaga pendidik yang belum bisa mengelolah kelas atau kesulitan selama pembelajaran online berlangsung akan menjadi hambatan siswa dalam memahami setiap pembelajaran berlangsung. ${ }^{23}$ Oleh sebab itu, pada mata

\footnotetext{
${ }^{21}$ Nanang Hanafiah dan Ccun Suhana, Konsep startegi Pembelajaran, (Bandung: Rafika Aditama, 2009), h. 69

${ }^{22}$ Wawancara dengan Guru PAI SD Dua Mei Ciputat, Siti Qomariah, M.Pd.I, 16 Juni 2021

${ }^{23}$ Pendi Susanto, Pandemi dan Anak Bangsa Menjadi Pintar, (Ciamis: Tsaqiva Publishing, 2021), h.5
} 
pelajaran PAI, Ibu Siti Qomariah, M.Pd.I mengganti strategi pembelajaran untuk meminimalisir kesulitan yang dialami selama pembelajaran online berlangsung.

Beliau juga mengatakan "Selama kurang lebih 4 bulan saya mengganti dengan menggunakan strategi pembelajaran kontekstual ini di kelas 4, kesulitan dan hambatan yang saya alami lebih berkurang dikarenakan strategi pembelajaran kontekstual lebih tidak membosankan karena dengan startegi pembelajaran ini setiap siswa dapat mengaitkan setiap materi pelajaran PAI dengan keadaan sekitar sehingga mereka lebih aktif dan memahami materi yang diajarkan" ${ }^{24}$

Dari pembahasan-pembahasan di atas penulis dapat menyimpulkan bahwa strategi pembelajaran yang dipakai untuk mengatasi kesulitan dalam kegiatan belajaran mengajar di kelas 4 di era pandemi Covid-19 ini adalah strategi pembelajaran kontekstual, dikarenakan strategi pembelajaran kontekstual merupakan pembelajaran yang mengaitkan materi pelajaran dengan kehidupan sehari-hari sehingga siswa dapat cepat memahami materi yang diajarkan. Strategi pembelajaran kontekstual ini juga telah meminimalisir kesulitan dan hambatan siswa seperti jenuh, bosan, dan kurang memahami materi pelajaran. Siswa kelas 4 lebih bisa menguasai materi pelajaran yang diberikan dan letak kejenuhan menjadi berkurang.

\section{Faktor Penghambat dan Pendukung dalam Mengatasi Kesulitan Selama Pembelajaran di Era Covid-19}

Selain strategi pembelajaran terdapat juga faktor penghambat dan pendukung selama pembelajaran di era pandemi Covid-19 ini. Faktor penghambat dan pendukungnya ialah orang tua dan fasilitas.

Dalam kondisi pandemi Covid-19 ini, selain strategi pembelajaran guru, peran orang tua juga harus ada selama proses pembelajaran online berlangsung. Orang tua adalah salah satu pendidik yang ada di rumah. Dalam keadaan pandemi Covid-19, orang tua berperan penting untuk mendidik dan mendampingi anak mereka ketika belajar, karena anak-anak masih perlu pemantauan dalam belajar secara online. ${ }^{25}$

\footnotetext{
${ }^{24}$ Wawancara dengan Guru PAI SD Dua Mei Ciputat, Siti Qomariah, M.Pd.I, 16 Juni 2021.

${ }^{25}$ Siti Maemunah dan Muhammad Alif, Peran Guru, Orang Tua, Metode dan Media Pembelajaran: Strategi KBM di Masa Pandemi Covid-19, ( Serang: Penerbit 3M Media Karya Serang, 2020), h.4
} 


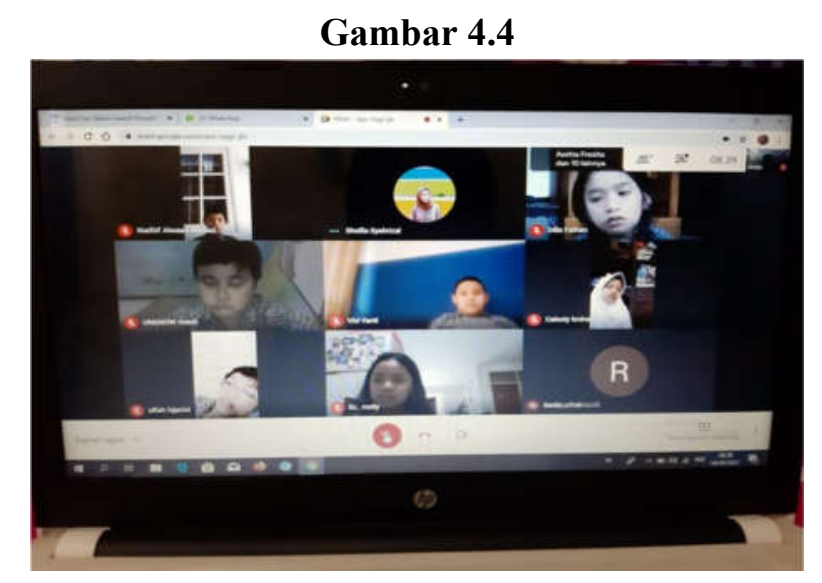

KBM PAI Online Kelas 4 SD Dua Mei Ciputat

Terlebih lagi untuk sederajat anak SD, bimbingan dan dorongan orang tua sangat dibutuhkan dan harus adanya koordinasi antara guru dan orang tua, seperti yang dikatakan oleh Ibu Siti Qomariah, M.Pd.I,

"Selama pembelajaran online berlangsung khususnya pada mata pelajaran PAI, saya mengadakan koordinasi yang dibantu oleh orang tua di rumah, karena untuk anak SD kelas 4 masih banyak sekali yang kurang memahami dalam penggunaan teknologi, bahkan ada orang tua siswa juga yang belum terlalu paham dalam menggunakan teknologi khususnya dalam penggunaan internet". ${ }^{26}$

Adapun dikatakan oleh siswa kelas 4 yang bernama Mutia "Selama belajar online orang tua saya yang mengatur untuk memulai pelajaran karena saya belum mengerti dalam penggunaan internet”. Berbeda dengan yang dikatakan oleh siswa kelas 4 yang bernama Rezki "Orang tua saya tidak mengerti akan penggunaan internet, jadi selama pelajaran online orang tua saya mengikuti arahan dari sekolah".

Dari pemaparan tersebut dapat dilihat bahwa sangat dibutuhkannya peran orang tua selama pembelajaran online berlangsung apalagi untuk jenjang SD dan perlunya peran orang tua dalam mengetahui teknologi khusunya internet untuk membantu anaknya selama pembelajaran online.

Dalam hal ini, SD Dua Mei melakukan upaya untuk meminimalisir kesulitan dan faktor penghambat yang terjadi pada peran orang tua, seperti yang dikatakan oleh kepala sekolah Ibu Siti Badriyah, M.Pd.I, "Selama pembelajaran online ini, SD Dua Mei telah berkoordinasi bersama wali murid atau orang tua untuk berperan aktif selama pembelajaran online berlangsung, dengan ini kami membuat grup WhatsApp bersama orang tua siswa untuk sama-sama mengontrol

${ }^{26}$ Wawancara dengan Guru PAI SD Dua Mei Ciputat, Siti Qomariah, M.Pd.I, 16 Juni 2021 
proses pembelajaran online". ${ }^{27}$ Ibu Qomariyah, M.Pd.I menambahkan, "Jadi, ketika 30 menit akan dimulainya pembelajaran PAI di kelas 4, saya telah mengirimkan Link di grup WhatsApp orang tua siswa sebagai akses untuk menyambungkan ke aplikasi yang akan dipakai dalam pembelajaran online, baik itu Zoom maupun Google Meet". 28

Jadi, dapat disimpulkan bahwa peran orang tua selama pembelajaran online sangat dibutuhkan untuk menunjang keefektifan selama pembelajaran berlangsung dan untuk di SD Dua Mei sendiri telah mempunyai solusi untuk meninimalisir terjadinya kesulitan selama pembelajaran online, yaitu dengan berkoordinasi dengan orang tua siswa melalui grup WhatsApp.

Selain strategi pembelajaran dan peran orang tua, fasilitas juga menjadi salah satu faktor penghambat dan pendukung dalam kesulitan selama pembelajaran online berlangsung. Berbagai perubahan dalam fasilitas pembelajaran terjadi, seperti halnya kebutuhan akses internet, kuota internet, ketersedian gadget, sinyal intenet, serta ketersediaan berbagai media pembelajaran yang menjadi salah satu modal dasar dalam pembelajaran online. ${ }^{29}$

Perubahahan fasilitas ini juga menjadi kesulitan dan hambatan yang sering terjadi selama pembelajaran online seperti yang telah dijelaskan oleh Ibu Siti Qomariah, M.Pd.I.

"Salah satu yang menyebabkan terjadinya hambatan dan kesulitan selama berlangsungnya pembelajaran yaitu masalah fasilitas atau teknis. Hal ini dikarenakan pembelajaran online membutuhkan akses internet yang memadai, karena ketika saya sedang mengajar di kelas 4 sering kali terjadinya gangguan dari jaringan internet yang menyebabkan hilangsnya konsentrasi dan fokus siswa". ${ }^{30}$

Hilangnya koneksi internet secara tiba-tiba adalah salah satu faktor yang sering terjadi dalam pembelajaran online, apalagi seorang pendidik atau guru menjadi sumber utama dalam pembelajaran online ini. Oleh karena itu, SD Dua Mei Ciputat telah mengambil langkah agar koneksi jaringan internet para guru tetap stabil selama pembelajaran online berlangsung. SD Dua Mei telah memberikan fasilitas berupa Wifi sekolah yang dapat digunakan selama pembelajaran online berlangsung agar meminimalisir terjadinya koneksi internet yang tidak stabil. Seperti yang telah dijelskan oleh kepala sekolah Ibu Siti Badriyah, M.Pd.I "Saya telah memberikan fasilitas berupa Wifi sekolah untuk para guru agar sinyal dan koneksi internet berjalan baik selama pembelajaran. Oleh

\footnotetext{
23 Juni 2021

${ }^{27}$ Wawancara dengan Kepala Sekolah SD Dua Mei Ciputat, Siti Badriyah, M.Pd.I, Via WhatsApp,

${ }^{28}$ Wawancara dengan Guru PAI SD Dua Mei Ciputat, Siti Qomariah, M.Pd.I, 16 Juni 2021

${ }^{29}$ Dina Alfiana Ikhwani, Strategi Pembelajaran Efektif Masa Pandemi Covid-19, (Bandung: Media Sains Indonesi, 2021), h.2

${ }^{30}$ Wawancara dengan Guru PAI SD Dua Mei Ciputat, Siti Qomariah, M.Pd.I, 16 Juni 2021
} 
karena itu juga, setiap pembelajaran berlangsung setiap guru diwajibkan untuk hadir di sekolah". ${ }^{31}$

Tetapi bukan hanya fasilitas yang dirasakan oleh guru, tapi juga yang dirasakan siswa. Banyak siswa yang memiliki jaringan internet yang kurang stabil selama berlakunya pembelajaran online. Seperti yang dikatakan oleh siswa kelas 4 yang bernama Mutia, "Selama pembelajaran online berlangsung jaringan internet yang saya gunakan sering kali tidak stabil bahkan pernah terjadi jaringannya tidak bisa digunakan”. Kemudian Ibu Siti Qomariah, M. Pd.I berpendapat juga, "Jadi, ketika saya telah memiliki solusi dalam masalah teknis seperti jaringan internet ini, ada masalah terbesar juga yaitu jaringan para siswa, khususnya di kelas 4 ini diantara mereka banyak tidak stabil setiap berlangsungnya pembelajaran". ${ }^{32}$

Banyak siswa yang merasakan faktor penghambat dari pembelajaran online ini, tidak sedikit siswa yang akhirnya tidak mengikuti pembelajaran dikarenakan minimnya akses internet. Hal ini diakibatkan jika terganggunya jaringan internet maka terganggu juga proses pembelajaran karena pembelajaran online pasti sangat membutuhkan jaringan internet yang baik.

Faktor penghambat pembelajaran online:

a. Pembelajaran online dirasa tidak menyenangkan bagi siswa karena banyak yang merasakan gangguan sinyal.

b. Borosnya penggunaan paket internet.

c. Siswa sulit memahami pelajaran ketika sinyal tidak stabil. ${ }^{33}$

Dengan adanya faktor penghambat tersebut,seperti yang telah dijelaskan oleh Ibu Siti Qomariah, M.Pd.I, "Ketika pembelajaran PAI berlangsung, ada lebih dari 3 orang anak yang mengalami kesulitan dalam jaringan maka pembelajaran PAI tidak menggunakan media Zoom ataupun Google Meet tetapi diganti dengan grup WhatsApp". ${ }^{4}$ Sama seperti yang dikatakan oleh Rezki, "Ketika saya mengalami kesulitan dan sinyal saya tidak bisa mengikuti pelajaran tetapi saya memantau dari grup WhatsApp agar tidak ketinggalan informasi tentang pembelajaran".

Sehingga dapat dijelaskan faktor penghambat yang sering terjadi adalah gangguan jaringan internet. Akan tetapi, SD Dua Mei Ciputat telah menemukan faktor pendukungnya yaitu ketika ada siswa lebih dari 3 orang yang mengalami kesulitan dalam jaringan internet maka pembelajaran tidak dilakukan dengan menggunakan Zoom ataupun Google Meet karena aplikasi ini membutuhkan jaringan internet yang baik baru bisa digunakan, tetapi dialokasikan pembelajaran

\footnotetext{
23 Juni 2021

${ }^{31}$ Wawancara dengan Kepala Sekolah SD Dua Mei Ciputat, Siti Badriyah, M.Pd.I, Via WhatsApp,

${ }^{32}$ Wawancara dengan Guru PAI SD Dua Mei Ciputat, Siti Qomariah, M.Pd.I, 16 Juni 2021

${ }^{33}$ Nisaul Chaoiroh, Efektivitas Pembelajaran Daring Dalam Pandangan Peserta Didik, Jurnal Pendidikan, Vol.07, No.2, 2020, h.203

${ }^{34}$ Wawancara dengan Guru PAI SD Dua Mei Ciputat, Siti Qomariah, M.Pd.I, 16 Juni 2021
} 
dengan grup WhatsApp, yaitu dengan pemberian tugas atau pun penjelasan guru dengan Voice Note WhatsApp.

Tetapi, terdapat faktor pendukung dari pembelajaran online yaitu:

a. Dapat memanfaatkan teknologi pada kegiatan pembelajaran.

b. Penggunakan smartphone dan leptop dapat memudahkan dalam proses pembelajaran online berlangsung.

c. Wawasan yang luas dengan pembelajaran online bisa mengases pengetahuan diamana saja. ${ }^{35}$

Dari pembahasan-pembahasan tersebut penulis dapat menjelaskan bahwa terdapat faktor penghambat dan pendukung selama berlakunya pembelajaran online, yaitu peran orang tua dan fasilitas. Peran orang tua untuk menunjang keberhasilan selama pembelajaran online berlangsung, yaitu dengan membuat grup WhatsApp bersama orang tua. Dengan adanya grup WhatsApp bisa memudahkan guru memberikan informasi mengenai materi pembelajaran yang kurang dimengeti dan yang mengalami masalah dalam jaringan internet. Terakhir, fasilitas yang digunakan selama pembelajaran online, yang berupa Wifi sekolah sangat membantu guru dalam berlangsungnya pembelajaran, sehingga jaringan internet menjadi stabil.

Dari sini penulis dapat menyimpulkan faktor pendukung dan penghambat dalam menghadapi kesulitan pembelajaran di kelas 4 SD Dua Mei Ciputat pada era pandemi Covid-19. Adapun faktor pendukungnya adalah sebagai berikut:

a. Inovasi Strategi Pembelajaran

b. Bantuan fasilitas Wifi sekolah terhadap guru

c. Koordinasi yang baik antara orang tua dan guru

Sedangkan faktor penghambatnya adalah sebagai berikut:

a. Jaringan Internet yang kurang stabil

b. Adanya beberapa orang tua yang belum mengerti dalam penggunaan internet.

c. Kompetensi siswa menurun.

${ }^{35}$ R.Gilang K.,Pelaksanaan Pembelajaran Daring di Era Covid-19, (Banyumas: Lutfi Gilang, 2020), h.36-38 


\section{KESIMPULAN}

Strategi pembelajaran merupakan peran yang begitu penting di dalam berlangsungnya kegiatan belajar mengajar. Terlebih pada saat pembelajaran online dimasa pandemi covid-19. Berdasarkan hasil dari wawacara dan observasi penulis, dapat disimpulkan bahwa guru PAI di SD Dua Mei Ciputat menggunakan strategi kontekstual dalam mengatasi kesulitan proses kegiatan belajar mengajar selama pandemi covid-19. Strategi pembelajaran kontekstual adalah strategi pembelajaran yang bersifat holistik dan bertujuan membantu para siswa untuk memahami makna dari materi pembelajaran dengan mengaitkannya terhadap konteks kehidupan mereka. Dengan strategi ini kesulitan kegiatan belajaran mengajar pada pelajaran PAI dikelas 4 dapat di diminimalisir.

Selain dari strategi pembelajaran yang digunakan oleh guru PAI di Sd Dua Mei Ciputat dalam mengatasi kesulitan kegiatan belajar mengajar di kelas 4 pada era pandemi covid-19, terdapat juga beberapa faktor pendukung dan penghambat dalam mengatasi kesulitan kegitan belajar mengajar di SD Dua Mei Ciputat selama pandemi covid-19 khususnya pada pelajaran PAI. Adapun faktor pendukungnya ialah inovasi strategi pembelajaran, bantuan fasilitas Wifi sekolah terhadap guru dan koordinasi yang baik antara orang tua dan guru. Sementara faktor penghambatnya ialah jaringan internet yang kurang stabil, adanya beberapa orang tua yang belum mengerti dalam penggunaan internet dan kompetensi siswa menurun. 


\section{DAFTAR PUSTAKA}

Chaoiroh, Nisaul. Efektivitas Pembelajaran Daring Dalam Pandangan Peserta Didik. Jurnal Pendidikan, Vol.07, No.2, 2020.

Haidir dan Salim. Strategi Pembelajaran: Suatu Pendekatan Bagaimana Meningkatkan Kegiatan Belajar Siswa Secara Transformatif. Medan: Perdana Publishing, 2014.

Hanafiah, Nanang dan Ccun Suhana. Konsep startegi Pembelajaran. Bandung: Rafika Aditama, 2009.

Haudi. Strategi Pembelajaran. Sumatra Barat: Insan Cedika Mandiri, 2021.

Ikhwani, Dina Alfiana. Strategi Pembelajaran Efektif Masa Pandemi Covid-19. Bandung: Media Sains Indonesi, 2021.

Kurniasari, Asrilia dkk. Analisis Efektivitas Pelaksanaan Belajar Dari Rumah Selama Pendemi Covid-19, dalam Jurnal Kajian Pendidikan dan Hasil Penelitian. Vol.6 No.3 2020.

Lutfi, Adi Muhammad dkk. Media Daring (Online) Solusi Pembelajaran Jarak Jauh. Parepare: IAIN Parepare Nusantara Press, 2020.

Maemunah, Siti dan Muhammad Alif. Peran Guru, Orang Tua, Metode dan Media Pembelajaran: Strategi KBM di Masa Pandemi Covid-19. Serang: Penerbit 3M Media Karya Serang, 2020.

Ngalimun. Strategi Pembelajaran. Yogyakarta: Parama Ilmu, 2017.

Nurdyansyah dan Eni Fariyatul Fahyuni. Inovasi Model Pembelajaran. Sidoarjo: Nizamia Learning Center, 2016.

R.Gilang K. Pelaksanaan Pembelajaran Daring di Era Covid-19. Banyumas: Lutfi Gilang, 2020.

Ragin, Gestiana dkk. Implementasi Strategi Pembelajaran Ekspositori untuk Meningkatkatkan Hasil Belajar Matematika di Sekolah Dasar: Jurnal Pendidikan Dakwah. Universutas Muhammadiyah Tangerang, 2020, Vol.02, No 1

Sadikin, Ali. Pembelajaran Daring di Tengah Wabah Covid-19, dalam Jurnal Pendidikan Biologi. Universitas Jambi, 2020, Vol.6, No.02

Sanjaya, Wina. Strategi Pembelajaran Berorietasi Standar Proses Pendidikan. Jakarta: Kencana Prenadamedia Group, 2006.

Suryadi. Strategi Pembelajaran Pendidikan Karakter. Bandung: PT. Remaja Rosdakarya, 2013.

Susanti, Lidia. Strategi Pembelajaran Online yang Inspiratif. Jakarta: PT. Gramedia, 2021.

Susanto, Pendi. Pandemi dan Anak Bangsa Menjadi Pintar. Ciamis: Tsaqiva Publishing, 2021. 
Qiro'ah| Jurnal Pendidikan Agama Islam

Wawancara dengan Guru PAI SD Dua Mei Ciputat, Siti Qomariah, M.Pd.I

Wawancara dengan Kepala Sekolah SD Dua Mei Ciputat, Siti Badriyah, M.Pd.I 